\title{
PENGARUH PEMBELAJARAN TANDUR BERBANTUAN MATHLET GEOGEBRA TERHADAP PEMAHAMAN KONSEP MATEMATIKA DITINJAU DARI KEMAMPUAN VISUAL
}

\author{
Oleh : \\ *Ni Made Yuning Sari Parwati ${ }^{1)}$, Gede Suweken') , I Gusti Putu Sudiarta ${ }^{3)}$ \\ Fakultas Matematika dan Ilmu Pengetahuan Alam, Universitas Pendidikan Ganesha ${ }^{1.2 .3)}$
}

\begin{abstract}
Abstrak
Penelitian ini bertujuan untuk mengetahui pengaruh pembelajaran TANDUR berbantuan mathlet Geogebra terhadap pemahaman konsep matematika ditinjau dari kemampuan visual siswa. Jenis penelitian ini merupakan penelitian eksperimen semu dengan rancangan treatment by level designs pada topik teorema Pythagoras. Populasi penelitian yaitu siswa kelas VIII SMP Negeri 12 Denpasar sebanyak 393 siswa tersebar dalam 10 kelas. Pengambilan sampel dilakukan dengan teknik cluster random sampling. Data pemahaman konsep matematika siswa dikumpulkan dengan tes uraian dan data kemampuan visual siswa dikumpulkan dengan tes pilihan ganda. Data yang diperoleh dianalisis menggunakan Uji-t dengan taraf signifikansi 5\%. Hasil penelitian menunjukkan bahwa: Pemahaman konsep matematika siswa yang mengikuti pembelajaran TANDUR berbantuan mathlet Geogebra lebih baik daripada siswa yang mengikuti pembelajaran TANDUR. Hasil yang sama juga diperoleh baik untuk siswa yang memiliki kemampuan visual lebih tinggi maupun lebih rendah. Namun, siswa yang memiliki kemampuan visual lebih tinggi lebih mudah untuk memahami konsep matematika yang bersifat abstrak. Dengan demikian pembelajaran TANDUR berbantuan mathlet Geogebra berpengaruh positif terhadap pemahaman konsep matematika ditinjau dari kemampuan visual siswa.
\end{abstract}

Kata Kunci: TANDUR berbantuan Mathlet GeoGebra, Pemahaman Konsep Matematika, Teorema Pythagoras, dan Kemampuan Visual.

\section{Abstract}

This research aimed to determine the effect of TANDUR learning assisted mathlet Geogebra on students' mathematical conceptual understanding reviewed of students' visual abilities. The type of this research is a quasi-experimental with treatment by level designs on the topic of the Pythagorean theorems. The population of this research were 393 students spread in 10 classes in grade $8^{\text {th }}$ of SMP N 12 Denpasar. The sample was determined using cluster random sampling technique. There were two data of this research, namely students's mathematical conceptual understanding and students' visual ability which were collected by essay and multiple choices test respectively. The data obtained were analyzed using t-test with significance level of 5\%. The results showed that the students' mathematical conseptual understanding who follows TANDUR learning assisted mathlet Geogebra was better than the students who follow the TANDUR learning only. The same results were also obtained for students with higher or lower visual abilities. However, students who have higher levels of visual abilities were easier to understand abstract mathematical concepts. Thus the TANDUR learning assisted mathlet Geogebra affect positively the students's mathematical conceptual understanding in terms of students' visual abilities.

Key words: TANDUR learning assisted mathlet Geogebra, mathematical conceptual understanding, Pythagorean theorems, and visual ability

\section{PENDAHULUAN}

Pemahaman terhadap teorema Pythagoras sangat penting bagi siswa. Hal ini digunakan sebagai alat untuk menyelesaikan beragam permasalahan matematika seperti menghitung diagonal bidang dan ruang, menghitung nilai sin, cos, tan, serta menentukan sudut-sudut istimewa pada trigonometri. Teorema Pythagoras merupakan materi dasar dalam mempelajari konsep matematika yang lebih kompleks (Sultan, 2009; Percy \& Carr, 2010; Muchyidin, 2012; Priyanto \& Trapsilasiwi, 2015; Rahayu, 2016 \& Foster, 2013). Oleh karena itu, teorema Pythagoras harus dikuasai siswa sebagai bekal untuk mempelajari konsep-konsep matematika selanjutnya. 
JURNAL MathEdu (Mathematic Education Journal) http://journal.ipts.ac.id/index.php/MathEdu

Vol. 4 No. 2 Juli 2021

Namun, hasil penelitian Priyanto \& Trapsilasiwi (2015); Sulistyawan \& Ariyanto (2017) menyatakan masih banyak siswa kesulitan dalam memahami teorema Pythagoras. Hal ini terlihat dari kesalahan siswa menyelesaikan soal cerita yang berkaitan dengan teorema Pythagoras. Adapun kesalahan yang sering dilakukan siswa, yaitu (1) menuliskan kata kunci dan tidak dapat mengilustrasikan soal kedalam gambar sebesar 43\%; (2) menuliskan apa yang diketahui dan apa yang ditanyakan tidak sesuai permintaan soal sebesar 46\%; (3) penggunaan rumus sebesar 49\% serta perhitungan yang kurang tepat sebesar 55\%; dan (4) penarikan kesimpulan sebesar 61\%. Paparan kesalahan siswa tersebut menandakan lemahnya pemahaman teorema Pythagoras siswa. Hanifah (2011) juga mengemukakan sebagian besar kesalahan siswa dalam menyelesaikan soal cerita dikarenakan mereka kurang memahami konsep yang ada. Padahal hal terpenting dalam pembelajaran matematika adalah memahami konsep dari matematika itu sendiri. Seperti yang dinyatakan Mwakapenda (2004); Cai \& Ding (2017); Agustina (2016); Wibawa \& Masduki (2017), yaitu pembelajaran matematika menekankan pada pemahaman konsep. Artinya dalam mempelajari matematika siswa harus memahami konsep terlebih dahulu agar dapat menyelesaikan soalsoal serta mengaplikasikan konsep tersebut di dunia nyata.

Pemahaman siswa terhadap konsep matematika menurut NCTM (2000), yaitu (1) menyatakan konsep dengan kata-kata sendiri; (2) mengidentifikasi contoh dan bukan contoh dari konsep; dan (3) mengaplikasikan konsep dengan benar dalam berbagai situasi. Siswa yang mencapai ketiga indikator ini dikatakan telah mampu memahami konsep matematika dengan baik. Melalui pemahaman konsep, siswa lebih mudah memahami materi dan mampu mengaplikasikannya dalam permasalahan sehari-hari. Jadi, pemahaman terhadap konsep-konsep matematika merupakan dasar untuk belajar matematika secara bermakna.

Mengingat pentingnya peranan pemahaman konsep matematika siswa khususnya pada teorema Pythagoras, maka perlu adanya upaya perbaikan dalam proses pembelajaran. Pembelajaran hendaknya dilaksanakan dalam situasi yang interaktif, inspiratif, menyenangkan, dan memotivasi. Disamping itu, memberikan keluasan kepada siswa dalam mengkonstruksi pengetahuannya sendiri serta pengajaran harus bertolak dari pengalaman yang dimiliki oleh siswa. Salah satu pembelajaran yang memfasilitasi hal tersebut adalah pembelajaran TANDUR. Pembelajaran TANDUR (yang merupakan singkatan dari Tumbuhkan, Alami, Namai, Demonstrasikan, Ulangi dan Rayakan) merupakan pembelajaran yang dikembangkan dari model pembelajaran quantum teaching (Trisnawati \& Wutsqa, 2015; Fermantika, 2012; Linto, 2012; \& Astawa, 2004). Pembelajaran ini menekankan agar siswa mengetahui dan memahami bentuk nyata dari pembelajaran yang berlangsung dengan bantuan aktivitas yang diberikan oleh guru. Hal tersebut membuat siswa tidak menghayal dalam mempelajari suatu konsep matematika. Sehingga siswa mampu mengungkapkan konsep matematikanya dengan bahasa yang benar dan mudah dipahami. Siswa juga lebih bebas menemukan berbagai pengalaman baru dalam belajarnya, sehingga dapat menciptakan belajar yang bermakna bagi siswa.

Penerapan pembelajaran TANDUR akan menjadi lebih optimal, efektif, dan bermakna apabila didukung dengan adanya media pembelajaan. Salah satu media pembelajaran yang dapat mendukung penerapan pembelajaran TANDUR adalah mathlet Geogebra. Geogebra adalah media pembelajaran yang dibuat dengan menggunakan berbagai tool maupun perintah yang tersedia, atau mengkombinasikannya dengan bahasa pemrograman Javascript (Suweken, 2013). Dengan kemampuan ini, Geogebra dapat menjadi media yang ampuh untuk memvisualisasikan konsep-konsep matematika yang bersifat abstrak. Sehingga siswa tidak lagi menghayal dalam mempelajari suatu konsep matematika dan akan lebih termotivasi untuk mengikuti pembelajaran. Mengkongkretkan konsep-konsep matematika yang bersifat abstrak dapat dilakukan dengan melambangkan sebagai simbol, gambar atau objek nyata dalam kehidupan sehari-hari. Menurut Wahidin (2010) penggunaan benda-benda konkrit ataupun alat-alat peraga sebagai sumber belajar dapat membuat siswa aktif dalam mengkonstruksi pengetahuannya sendiri. Hal ini dapat mengatasi rutinitas pembelajaran yang membosankan dan sangat tepat dengan kondisi perkembangan mental siswa di sekolah menengah pertama. Penggunaan benda-benda kongkrit ataupun alat-alat peraga merupakan representasi visual. Dengan adanya representasi visual tersebut maka adanya peranan penting kemampuan visual siswa. Kemampuan visual merupakan proses mental dalam mengamati dan menggambarkan kembali sesuai dengan apa yang sudah "dilihatnya". Dengan kemampuan visual ini siswa mampu menyederhanakan masalah, melihat keterkaitan masalah, serta mampu mengubah masalah ke dalam bentuk matematis. Jadi, siswa yang memiliki tingkat kemampuan visual lebih tinggi akan lebih mudah untuk memahami konsep matematika yang bersifat abstrak (Mrstik \& Pearl, 2018).

Berdasarkan paparan diatas, maka penulis memandang perlu untuk melakukan penelitian lebih lanjut tentang pengaruh pembelajaran TANDUR berbantuan mathlet Geogebra terhadap pemahaman konsep matematika siswa pada materi teorema Pythagoras ditinjau dari kemampuan visual siswa 
ISSN. 2621-9832

JURNAL MathEdu (Mathematic Education Journal) http://journal.ipts.ac.id/index.php/MathEdu

Vol. 4 No. 2 Juli 2021

Terdapat beberapa permasalahan yang diangkat dalam penelitian ini, yakni: (1) Apakah pemahaman konsep matematika siswa pada materi teorema Pythagoras yang mengikuti pembelajaran TANDUR berbantuan mathlet Geogebra lebih baik daripada siswa yang mengikuti pembelajaran TANDUR? (2) Pada kelompok siswa yang memiliki tingkat kemampuan visual lebih tinggi, apakah pemahaman konsep matematika siswa pada materi teorema Pythagoras yang mengikuti pembelajaran TANDUR berbantuan mathlet Geogebra lebih baik daripada siswa yang mengikuti pembelajaran TANDUR? dan (3) Pada kelompok siswa yang memiliki tingkat kemampuan visual lebih rendah, apakah pemahaman konsep matematika siswa pada materi teorema Pythagoras yang mengikuti pembelajaran TANDUR berbantuan mathlet Geogebra lebih baik daripada siswa yang mengikuti pembelajaran TANDUR?

\section{METODE PENELITIAN}

Penelitian ini merupakan bagian dari penelitian yang lebih besar yang bertujuan untuk mengetahui pengaruh pembelajaran TANDUR berbantuan mathlet Geogebra terhadap pemahaman konsep matematika ditinjau dari kemampuan visual siswa. Jenis penelitian yang digunakan adalah penelitian eksperimen semu. Dalam penelitian ini terdapat satu variabel bebas yaitu pembelajaran TANDUR berbantuan mathlet Geogebra. Satu variabel terikat yaitu pemahaman konsep matematika pokok bahasan teorema Pythagoras. Serta satu variabel moderator, yaitu kemampuan visual siswa. Kemampuan visual siswa dibedakan menjadi dua level, yakni tingkat kemampuan visual lebih tinggi dan tingkat kemampuan visual lebih rendah. Sehingga rancangan yang digunakan adalah treatment by level designs. Desain ini memberikan dasar-dasar pengamatan stratifikasi yang lebih baik. Kita sadari bahwa setiap kelompok/kelas selalu ada siswa yang masuk kelompok tinggi atau rendah, maka melalui desain ini stratifikasi itu perlu mendapatkan perhatian dalam menentukan kelompok eksperimen dan kontrol (Supardi, 2011).

Populasi penelitian ini adalah seluruh siswa kelas VIII SMP Negeri 12 Denpasar tahun pelajaran 2017/2018 sebanyak 393 siswa tersebar dalam 10 kelas. Pengambilan sampel dilakukan dengan teknik cluster random sampling. Dalam penelitian ini, diambil dua kelas sebagai sampel dilakukan secara acak dengan sistem pengundian. Hasil pengundian tersebut, terpilih kelas VIIIF dan VIIIH sebagai kelas sampel penelitian. Dua kelas sampel yang terpilih dilakukan penyetaraan dengan menggunakan Uji-t untuk mengetahui ada tidaknya perbedaan rata-rata skor kemampuan awal matematika siswa. Setelah diperoleh sampel penelitian yang setara, dilakukan pengundian untuk menentukan perlakuan yang diterima masing-masing kelas sampel. Hasil pengundian adalah sebagai berikut: Kelas VIIIF sebagai kelas eksperimen memperoleh perlakuan berupa pembelajaran TANDUR berbantuan mathlet Geogebra dan Kelas VIIIH sebagai kelas kontrol memperoleh perlakuan berupa pembelajaran TANDUR.

Setiap kelompok selanjutnya diberikan tes kemampuan visual siswa untuk menentukan tinggi rendahnya kemampuan visual siswa. Pengelompokan siswa berdasarkan skor yang diperoleh dari tes kemampuan visual yang diberikan. Pengelompokkan siswa dapat diihat pada Tabel berikut.

Tabel 1

Pengelompokkan Siswa Berdasarkan Tes Kemampuan Visual Siswa

\begin{tabular}{|c|c|c|c|}
\hline $\begin{array}{l}\text { Kemampuan } \\
\text { Visual }\end{array}$ & $\begin{array}{l}\text { Pembelajaran } \\
\text { TANDUR } \\
\text { berbantuan mathlet } \\
\text { Geogebra }\end{array}$ & $\begin{array}{l}\text { Pembelajaran } \\
\text { TANDUR }\end{array}$ & Jumlah \\
\hline Lebih Tinggi & 13 & 13 & 26 \\
\hline Lebih Rendah & 13 & 13 & 26 \\
\hline Jumlah & 26 & 26 & 52 \\
\hline
\end{tabular}

Adapun prosedur penelitian ini: Pertama, menentukan populasi penelitian yaitu siswa Kelas VIII SMP Negeri 12 Denpasar. Kedua, melakukan cluster random sampling untuk memperoleh dua kelas sampel penelitian. Dua kelas sampel yang diperoleh selanjutnya diundi untuk menentukan kelas eksperimen dan kelas kontrol. Ketiga, memberikan tes kemampuan visual siswa kepada dua kelas yang terpilih untuk mengetahui tingkat kemampuan visual siswa. Keempat, memilah masing-masing kelas menjadi dua kelompok berdasarkan hasil tes kemampuan visual siswa, yaitu kelompok siswa yang memiliki tingkat kemampuan visual lebih tinggi dan kelompok siswa yang memiliki tingkat kemampuan visual lebih rendah. Kelima, mempersiapkan kelengkapan pembelajaran, seperti RPP, LKS dan mathlet Geogebra. Keenam, mengonsultasikan RPP, LKS serta mathlet Geogebra yang dibuat dengan dosen ahli 
ISSN. 2621-9832

JURNAL MathEdu (Mathematic Education Journal) http://journal.ipts.ac.id/index.php/MathEdu

Vol. 4 No. 2 Juli 2021

di bidang pendidikan matematika atau guru matematika yang berpengalaman. Ketujuh, menyusun instrumen penelitian berupa tes uraian untuk mengukur pemahaman konsep matematika siswa pokok bahasan teorema Pythagoras serta mengonsultasikan instrumen penelitian dengan dosen pembimbing. Kedelapan, mengadakan uji validitas isi dengan expert judgement (validitas ahli) terhadap instrumen penelitian kepada dosen ahli atau guru matematika. Kesembilan, melaksanakan uji coba instrumen pemahaman konsep matematika untuk menentukan validitas dan reliabilitas serta menganalisis hasil uji coba instrumen. Kesepuluh, memberikan perlakuan berupa pembelajaran TANDUR berbantuan mathlet GeoGebra pada kelas eksperimen dan pembelajaran TANDUR pada kelas kontrol. Kesebelas, memberikan post test kepada kelas sampel secara bersamaan serta menganalisis hasil post test untuk menguji hipotesis yang diajukan dan terakhir membuat laporas hasil penelitian.

Instrumen penelitian yang digunakan dalam penelitian ini berupa tes pemahaman konsep matematika siswa dan tes kemampuan visual siswa. Kedua tes ini masing-masing digunakan untuk mengumpulkan data pemahaman konsep matematika siswa dan data tingkat kemampuan visual siswa.

Tes pemahaman konsep matematika berupa soal uraian yang terdiri dari 8 butir soal diberikan pada akhir pertemuan pada kelompok sampel penelitian. Sedangkan tes kemampuan visual siswa berupa soal pilihan ganda terdiri dari 15 butir soal diberikan pada awal pertemuan untuk mengetahui tingkat kemampuan visual masing-masing kelompok sampel penelitian. Sebelum instrumen digunakan, terlebih dahulu dilakukan uji validitas isi oleh dua orang pakar guna mendapatkan kualitas instrumen yang baik, yang dilanjutkan dengan uji coba instrumen di lapangan, untuk mengetahui validitas dan reliabilitas instrumen tersebut.

Hasil dari uji coba tes pemahaman konsep matematika siswa yang terdiri dari 8 butir soal tersebut dinyatakan 2 butir soal tidak valid dan 6 butir soal dinyatakan valid. Dari keenam butir soal yang valid kemudian diuji tingkat reliabelnya, dari hasil uji coba disimpulkan bahwa instrumen tes pemahaman konsep matematika memiliki derajat reliabilitas sedang. Hasil uji coba dari tes kemampuan visual siswa yang terdiri dari 15 butir soal dinyatakan semuanya valid dan memiliki derajat reliabilitas sangat tinggi. Dengan hasil uji coba tersebut, instrumen tes pemahaman konsep matematika siswa dan tes kemampuan visual siswa layak digunakan dalam penelitian.

Data hasil penelitian dilakukan pengujian hipotesis dengan menggunakan Uji-t. Sebelum pengujian hipotesis, maka data penelitian harus memenuhi syarat, yaitu data berdistribusi normal dan memiliki varians yang homogen. Untuk itu dilakukan uji normalitas sebaran data dan uji homogenitas varians. Uji normalitas sebaran data menggunakan uji Liliefors sedangkan uji homogenitas varians menggunakan uji Bartlett.

\section{HASIL DAN PEMBAHASAN}

Hasil penelitian ini berupa data yang dikelompokkan menjadi: (1) pemahaman konsep matematika siswa yang mengikuti pembelajaran TANDUR berbantuan mathlet Geogebra (A1), (2) pemahaman konsep matematika siswa yang mengikuti pembelajaran TANDUR (A2), (3) pemahaman konsep matematika siswa yang mengikuti pembelajaran TANDUR berbantuan mathlet Geogebra dengan tingkat kemampuan visual lebih tinggi (A1B1), (4) pemahaman konsep matematika siswa yang mengikuti pembelajaran TANDUR berbantuan mathlet Geogebra dengan tingkat kemampuan visual lebih rendah (A1B2), (5) pemahaman konsep matematika siswa yang mengikuti pembelajaran TANDUR dengan tingkat kemampuan visual lebih tinggi (A2B1), dan (6) pemahaman konsep matematika siswa yang mengikuti pembelajaran TANDUR dengan tingkat kemampuan visual lebih rendah (A2B2). Dalam penelitian ini hanya terbatas pada materi teorema Pythagoras. Data-data tersebut disajikan dalam tabel berikut.

Tabel 2

Rekapitulasi Statistik Pemahaman Konsep Matematika Siswa

\begin{tabular}{lcccccc}
\hline \multirow{2}{*}{ Statistik } & \multicolumn{7}{c}{ Unit Analisis } \\
\cline { 2 - 7 } & A1 & A2 & A1B1 & A1B2 & A2B1 & A2B2 \\
\hline Mean & 61.25 & 54.25 & 66.12 & 56.38 & 59.50 & 49.00 \\
\hline Median & 63.00 & 54.50 & 66.00 & 60.00 & 60.00 & 50.00 \\
\hline $\begin{array}{l}\text { Standar } \\
\text { Deviasi }\end{array}$ & 8.66 & 10.25 & 4.86 & 9.01 & 9.88 & 7.84 \\
\hline Varians & 74.95 & 105.07 & 23.59 & 81.26 & 97.67 & 61.50 \\
\hline
\end{tabular}


ISSN. 2621-9832

JURNAL MathEdu (Mathematic Education Journal) http://journal.ipts.ac.id/index.php/MathEdu Vol. 4 No. 2 Juli 2021

\begin{tabular}{lcccccc}
\hline $\begin{array}{l}\text { Nilai } \\
\text { Tertinggi }\end{array}$ & 75.00 & 70.50 & 75.00 & 65.00 & 70.50 & 60.00 \\
\hline $\begin{array}{l}\text { Nilai } \\
\text { Terendah }\end{array}$ & 36.00 & 36.00 & 57.00 & 36.00 & 36.00 & 36.00 \\
\hline Rentangan & 39.00 & 34.50 & 18.00 & 29.00 & 34.50 & 24.00 \\
\hline
\end{tabular}

Sebelum dilakukan uji hipotesis, terlebih dahulu dilakukan uji normalitas dan homogenitas varians. Uji normalitas sebaran data pada kelompok sampel penelitian menggunakan Uji Lilliefors dapat dilihat pada Tabel 3 berikut.

Tabel 3

Rangkuman Uji Lilliefors

\begin{tabular}{ccc}
\hline Kelompok Sampel & $\boldsymbol{L}_{\text {hitung }}$ & $\boldsymbol{L}_{\text {tabel }}$ \\
\hline A1 & 0.1042 & 0.1386 \\
\hline A2 & 0.0779 & 0.1386 \\
\hline A1B1 & 0.1064 & 0.2337 \\
\hline A1B2 & 0.1696 & 0.2337 \\
\hline A2B1 & 0.1328 & 0.2337 \\
\hline A2B2 & 0.1052 & 0.2337 \\
\hline
\end{tabular}

Dari Tabel 3, dapat dilihat bahwa $L_{\text {hitung }}$ pada semua kelompok sampel kurang dari $L_{\text {tabel }}$ pada kelompok sampel yang bersangkutan maka dapat disimpulkan data pemahaman konsep matematika siswa pokok bahasan teorema Pythagoras setiap kelompok sampel berdistribusi normal.

Selanjutnya untuk uji homogenitas varians pada kelompok sampel A1 dan A2, diperoleh nilai $\chi^{2}=1.1359$ dengan nilai $\chi^{2}$-tabel $=3.841$. Ternyata $\chi^{2}$-hitung kurang dari $\chi^{2}$-tabel, sehingga dapat disimpulkan bahwa varians data kedua sampel homogen. Uji homogenitas varians pada kelompok sampel A1B1, A1B2, A2B1, dan A2B2 diperoleh nilai $\chi^{2}=6.4973$ dengan nilai $\chi^{2}$-tabel $=7.815$. Ternyata $\chi^{2}$-hitung kurang dari $\chi^{2}$-tabel, sehingga dapat disimpulkan bahwa varians data keempat sampel homogen.

Berdasarkan uji normalitas dan uji homogenitas diketahui bahwa data dari kelompok sampel berdistribusi normal dan homogen. Oleh sebab itu dapat dilakukan pengujian hipotesis dengan menggunakan Uji-t. Dalam penelitian ini terdapat tiga hipotesis,yaitu:

\section{Hipotesis pertama}

$\mathrm{H}_{0}: \mu_{1}=\mu_{2}$, pemahaman konsep matematika siswa pada materi teorema Pythagoras yang mendapat pembelajaran TANDUR berbantuan mathlet GeoGebra sama dengan siswa yang mendapat pembelajaran TANDUR.

$\mathrm{H}_{\mathrm{a}}: \mu_{1}>\mu_{2}$, pemahaman konsep matematika siswa pada materi teorema Pythagoras yang mendapat pembelajaran TANDUR berbantuan mathlet GeoGebra lebih baik daripada siswa yang mendapat pembelajaran TANDUR.

Rangkuman hasil pengujian hipotesis pertama dengan Uji- $t$ dapat dilihat pada Tabel 4 berikut.

Tabel 4

Rangkuman Pengujian Hipotesis Pertama

\begin{tabular}{cllll}
\hline Kelompok Sampel & $\mathbf{N}$ & Rata-rata & Varians & $\boldsymbol{t}_{\text {hit }}$ \\
\hline A1 & 26 & 61.25 & 74.945 & \multirow{2}{*}{2.660} \\
\hline A2 & 26 & 54.25 & 105.065 & \\
\hline
\end{tabular}

Sesuai dengan perhitungan pada Tabel 4 , diperoleh $t_{\text {hitung }}=2.660$. Adapun nilai $t_{\text {tabel }}$ pada taraf signifikasi

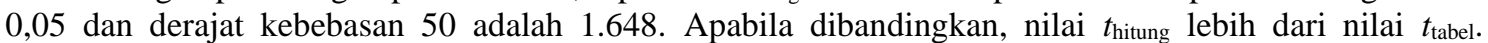
Dengan demikian $\mathrm{H}_{0}$ ditolak. Hal ini berarti pemahaman konsep matematika siswa pada materi teorema 
ISSN. 2621-9832

JURNAL MathEdu (Mathematic Education Journal) http://journal.ipts.ac.id/index.php/MathEdu

Vol. 4 No. 2 Juli 2021

Pythagoras yang mendapat pembelajaran TANDUR berbantuan mathlet Geogebra lebih baik daripada siswa yang mendapat pembelajaran TANDUR.

\section{Hipotesis kedua}

$\mathrm{H}_{0}: \mu \mathrm{A} 1 \mathrm{~B} 1=\mu \mathrm{A} 2 \mathrm{~B} 1$, pada kelompok siswa yang memiliki tingkat kemampuan visual lebih tinggi, pemahaman konsep matematika siswa pada materi teorema Pythagoras yang mendapat pembelajaran TANDUR berbantuan mathlet GeoGebra sama dengan siswa yang mendapat pembelajaran TANDUR

Ha: $\mu \mathrm{A} 1 \mathrm{~B} 1>\mu \mathrm{A} 2 \mathrm{~B} 1$, pada kelompok siswa yang memiliki kemampuan visual lebih tinggi, pemahaman konsep matematika siswa pada materi teorema Pythagoras yang mendapat pembelajaran TANDUR berbantuan mathlet GeoGebra lebih baik daripada siswa yang mendapat pembelajaran TANDUR.

Berdasarkan hasil perhitungan pengujian hipotesis kedua yang menggunakan Uji-t, dapat dilihat Tabel 5 berikut.

Tabel 5

Rangkuman Pengujian Hipotesis Kedua

\begin{tabular}{cllll}
\hline Kelompok Sampel & N & Rata-rata & Varians & $\boldsymbol{t}_{\text {hit }}$ \\
\hline A1B1 & 13 & 66.12 & 23.59 & \multirow{2}{*}{2.1661} \\
\cline { 1 - 4 } A2B1 & 13 & 59.50 & 97.67 & \\
\hline
\end{tabular}

Sesuai dengan perhitungan pada Tabel 5, diperoleh $t_{\text {hitung }}=2.1661$. Adapun nilai $t_{\text {tabel }}$ pada taraf signifikasi 0,05 dan derajat kebebasan 24 adalah 1,711. Apabila dibandingkan, nilai $t_{\text {hitung }}$ lebih dari nilai $t_{\text {tabel. }}$. Dengan demikian $\mathrm{H}_{0}$ ditolak. Hal ini berarti pada kelompok siswa yang memiliki kemampuan visual lebih tinggi, pemahaman konsep matematika siswa pada materi teorema Pythagoras yang mendapat pembelajaran TANDUR berbantuan mathlet GeoGebra lebih baik daripada siswa yang mendapat pembelajaran TANDUR.

\section{Hipotesis ketiga}

Ho : $\mu \mathrm{A} 1 \mathrm{~B} 2=\mu \mathrm{A} 2 \mathrm{~B} 2$, pada kelompok siswa yang memiliki tingkat kemampuan visual lebih rendah, pemahaman konsep matematika siswa pada materi teorema Pythagoras yang mendapat pembelajaran TANDUR berbantuan mathlet GeoGebra sama dengan siswa yang mendapat pembelajaran TANDUR.

Ha : $\mu \mathrm{A} 1 \mathrm{~B} 2>\mu \mathrm{A} 2 \mathrm{~B} 2$, pada kelompok siswa yang memiliki tingkat kemampuan visual lebih rendah, pemahaman konsep matematika siswa pada materi teorema Pythagoras yang mendapat pembelajaran TANDUR berbantuan mathlet GeoGebra lebih baik daripada siswa yang mendapat pembelajaran TANDUR.

Berdasarkan hasil perhitungan pengujian hipotesis ketiga yang menggunakan Uji-t, dapat dilihat pada Tabel 6 berikut.

Tabel 6

Rangkuman Pengujian Hipotesis Ketiga

\begin{tabular}{ccccc}
\hline Kelompok Sampel & $\mathbf{N}$ & Rata-rata & Varians & \multirow{2}{*}{$\boldsymbol{t}_{\text {hit }}$} \\
\hline A1B2 & 13 & 56.38 & 81.26 & \multirow{2}{*}{2.2284} \\
\cline { 1 - 4 } A2B2 & 13 & 49.00 & 61.50 & \\
\hline
\end{tabular}

Sesuai dengan perhitungan pada Tabel 6 , diperoleh $t_{\text {hitung }}=2.224$. Adapun nilai $t_{\text {tabel }}$ pada taraf signifikasi 0,05 dan derajat kebebasan 24 adalah 1,711. Apabila dibandingkan, nilai $t_{\text {hitung }}$ lebih dari nilai $t_{\text {tabel }}$. Dengan demikian $\mathrm{H}_{0}$ ditolak. Hal ini berarti pada kelompok siswa yang memiliki tingkat kemampuan visual lebih rendah, pemahaman konsep matematika siswa pada materi teorema Pythagoras yang mendapat pembelajaran TANDUR berbantuan mathlet Geogebra lebih baik daripada siswa yang mendapat pembelajaran TANDUR.

Berdasarkan uraian tentang hasil uji hipotesis diatas, dapat disajikan pembahasan sebagai berikut:

Pemahaman Konsep Matematika Siswa pada Materi Teorema Pythagoras yang Mengikuti Pembelajaran TANDUR berbantuan Mathlet Geogebra Lebih Baik daripada Siswa yang Mengikuti Pembelajaran TANDUR 
ISSN. 2621-9832

JURNAL MathEdu (Mathematic Education Journal) http://journal.ipts.ac.id/index.php/MathEdu

Vol. 4 No. 2 Juli 2021

Hasil analisis yang menggunakan Uji-t terhadap skor tes pemahaman konsep matematika siswa, diketahui bahwa rata-rata skor tes pemahaman konsep matematika siswa pada kelas eksperimen adalah 61.25 dan rata-rata skor tes pemahaman konsep matematika siswa pada kelas kontrol adalah 54.25.

Pengujian hipotesis penelitian bertujuan untuk melihat apakah pemahaman konsep matematika siswa pada materi teorema Pythagoras yang mengikuti pembelajaran TANDUR berbantuan mathlet Geogebra lebih baik daripada siswa yang mengikuti pembelajaran TANDUR. Hasil yang diperoleh pada pengujian ini adalah menolak $H_{0}$ dan menerima $H_{a}$, yang berarti pemahaman konsep matematika siswa pada materi teorema Pythagoras yang mengikuti pembelajaran TANDUR berbantuan mathlet Geogebra lebih baik daripada siswa yang mengikuti pembelajaran TANDUR.

Hal ini terjadi karena pembelajaran TANDUR berbantuan mathlet Geogebra menekankan agar siswa mengetahui dan memahami bentuk nyata dari pembelajaran yang berlangsung dengan bantuan aktivitas yang diberikan oleh guru. Pembelajaran TANDUR juga didukung dengan adanya media pembelajaran yang mampu mengubah suasana pembelajaran menjadi lebih efektif dan bermakna. Media pembelajaran yang dimaksud adalah mathlet Geogebra. Mathlet Geogebra ini sangat ampuh digunakan untuk mengeksplorasikan atau memvisualisasikan konsep-konsep matematika yang bersifat abstrak. Sehingga siswa tidak menghayal dalam mempelajari suatu konsep dan membuat siswa lebih termotivasi dalam mengikuti pembelajaran matematika. Hal ini sesuai dengan penelitian Eugen Ljajko (2013) yang berjudul "Development of ideas in a GeoGebra - aided mathematics instruction" menunjukkan adanya perubahan suasana pembelajaran siswa yang pasif menjadi aktif. Begitu pula dengan penelitian (Praveen \& Leong, 2012) yang berjudul “Effectiveness of Using GeoGebra on Students' Understanding in Learning Circles" yang menyatakan bahwa adanya efek positif dari penerapan mathlet GeoGebra dilihat dari perubahan sikap siswa menjadi lebih aktif dalam mengikuti proses pembelajaran. Keaktifikan siswa dalam mengikuti pembelajaran akan termotivasi untuk mengetahui lebih dalam mengenai pelajaran matematika itu sendiri.

Pembelajaran matematika dengan menerapkan pembelajaran TANDUR berbantuan mathlet Geogebra dimulai dengan penumbuhan minat siswa terhadap pembelajaran matematika. Pada tahap Tumbuhkan ini, guru menjalin interaksi dengan siswa dan menyakinkan mereka mengapa harus mempelajari materi ini. Tahap Alami, guru memberikan kesempatan kepada siswa untuk menyelesaikan permasalahan yang ada pada LKS dengan bantuan mathlet Geogebra sehingga siswa mengalami langsung hal-hal yang dipelajari. Tahap Namai, ketika minat dan perhatian telah tumbuh dan berbagai pertanyaan muncul dalam pikiran siswa, maka pada saat itu guru memberi informasi atau kata kunci terkait dengan materi yang dibahas. Penanaman konsep setelah mendapatkan pengalaman akan menjadikan sesuatu lebih bermakna dan berkesan bagi siswa. Tahap Demonstrasikan, guru memberikan kesempatan kepada siswa untuk mendemonstrasikan kemampuannya. Tahap Ulangi, guru memberikan evaluasi berupa kuis untuk mengetahui sejauh mana pemahaman siswa terhadap materi tersebut. Hal ini dimaksudkan untuk melakukan pengulangan terhadap materi yang telah dibahas karena semakin sering melakukan pengulangan, maka pengetahuan akan semakin mendalam. Tahap Rayakan yang merupakan tahap terakhir, guru memberikan penghargaan kepada siswa yang telah menunjukkan kemajuan dalam belajar. Dengan adanya tahapan-tahapan tersebut yang didukung oleh media pembelajaran, siswa cenderung lebih aktif dan tidak mengkayal dalam membayangkan suatu konsep yang dipelajari. Sehingga siswa mampu mengungkapkan konsep matematika dengan bahasa yang benar dan mudah dipahami, mengidentifikasi contoh atau bukan contoh dari konsep matematika serta mampu mengaplikasikan konsep matematika dengan benar dalam kehidupan sehari-hari. Hal ini sesuai dengan penelitian (Fermantika, 2012) dalam jurnalnya yang menyatakan bahwa hasil belajar matematika kelompok siswa yang menggunakan metode TANDUR lebih baik daripada hasil belajar matematika kelompok siswa yang menggunakan pembelajaran konvensional. Kunci dari peningkatan hasil belajar matematika siswa dikarenakan siswa sudah menguasai konsep dari matematika itu sendiri. Jadi usaha inovatif yang dilakukan pada tahapan-tahapan pembelajaran TANDUR memberikan dampak positif terhadap aktivitas siswa dalam mengikuti pembelajaran sehingga tercipta pembelajaran yang bermakna.

Pada Kelompok Siswa yang Memiliki Tingkat Kemampuan Visual Lebih Tinggi, Pemahaman Konsep Matematika Siswa pada Materi Teorema Pythagoras yang Mengikuti Pembelajaran TANDUR berbantuan Mathlet Geogebra Lebih Baik daripada Siswa yang Mengikuti Pembelajaran TANDUR 
ISSN. 2621-9832

JURNAL MathEdu (Mathematic Education Journal) http://journal.ipts.ac.id/index.php/MathEdu

Vol. 4 No. 2 Juli 2021

Hasil analisis yang menggunakan Uji-t terhadap skor tes pemahaman konsep matematika siswa, diketahui bahwa rata-rata skor tes pemahaman konsep matematika siswa pada kelas eksperimen adalah 66.12 dan rata-rata skor tes pemahaman konsep matematika siswa pada kelas kontrol adalah 59.50

Pengujian hipotesis penelitian bertujuan untuk melihat pada kelompok siswa yang memiliki tingkat kemampuan visual lebih tinggi, apakah pemahaman konsep matematika siswa pada materi teorema Pythagoras yang mengikuti pembelajaran TANDUR berbantuan mathlet Geogebra lebih baik daripada siswa yang mengikuti pembelajaran TANDUR. Hasil yang diperoleh pada pengujian ini adalah menolak $H_{0}$ dan menerima $H_{a}$, yang berarti pada kelompok siswa yang memiliki tingkat kemampuan visual lebih tinggi, pemahaman konsep matematika siswa pada materi teorema Pythagoras yang mengikuti pembelajaran TANDUR berbantuan mathlet Geogebra lebih baik daripada siswa yang mengikuti pembelajaran TANDUR.

Hasil tersebut menunjukkan bahwa strategi dan media pembelajaran yang digunakan harus didukung oleh kemampuan visual dari siswa. Karena dalam pemanfaatan media pembelajaran yaitu mathlet Geogebra sangat membantu mengefektifkan proses pembelajaran. Mathlet Geogebra ini digunakan untuk mengkongkretkan konsep-konsep teorema Pythagoras yang bersifat abstrak. Mengkonkretkan konsep-konsep teorema Pythagoras dapat dilakukan dengan melambangkan sebagai simbol, gambar, atau objek nyata dalam kehidupan sehari-hari. Simbol, gambar, atau objek nyata merupakan representasi visual. Maka dari itu, siswa yang memiliki tingkat kemampuan visual tinggi lebih mudah memahami konsep teorema Pythagoras dengan pembelajaran TANDUR berbantuan mathlet Geogebra. Hal ini sesuai dengan penelitian (Mrstik \& Pearl, 2018) yang menyatakan bahwa dengan tingkat kemampuan visual lebih tinggi, siswa akan lebih mudah untuk memahami konsep yang bersifat abstrak dalam maematika.

Pada Kelompok Siswa yang Memiliki Tingkat Kemampuan Visual Lebih Tinggi, Pemahaman Konsep Matematika Siswa pada Materi Teorema Pythagoras yang Mengikuti Pembelajaran TANDUR berbantuan Mathlet Geogebra Lebih Baik daripada Siswa yang Mengikuti Pembelajaran TANDUR

Hasil analisis yang menggunkan Uji-t terhadap skor tes pemahaman konsep matematika siswa, diketahui bahwa rata-rata skor tes pemahaman konsep matematika siswa pada kelas eksperimen adalah 56.38 dan rata-rata skor tes pemahaman konsep matematika siswa pada kelas kontrol adalah 49.00.

Pengujian hipotesis penelitian bertujuan untuk melihat pada kelompok siswa yang memiliki tingkat kemampuan visual lebih rendah, apakah pemahaman konsep matematika siswa pada materi teorema Pythagoras yang mengikuti pembelajaran TANDUR berbantuan mathlet Geogebra lebih baik daripada siswa yang mengikuti pembelajaran TANDUR. Hasil yang diperoleh pada pengujian ini adalah menolak $H_{0}$ dan menerima $H_{a}$, yang berarti pada kelompok siswa yang memiliki tingkat kemampuan visual lebih rendah, pemahaman konsep matematika pada materi teorema Pythagoras yang mengikuti pembelajaran TANDUR berbantuan mathlet Geogebra lebih baik daripada siswa yang mengikuti pembelajaran TANDUR.

Hasil tersebut menunjukkan bahwa siswa yang memiliki kemampuan visual lebih rendah cenderung lebih sulit untuk memahami konsep matematika pada materi teorema Pythagoras. Hal ini dikarenakan kemampuan visual sangat mendukung proses pembelajaran khususnya yang melibatkan media pembelajaran, yaitu mathlet Geogebra. Karena mathlet Geogebra ini membantu mengkongkretkan konsep-konsep teorema Pythagoras yang bersifat abstrak dengan melambangkan sebagai simbol, gambar, atau objek nyata dalam kehidupan sehari-hari. Hal tersebut merupakan representasi visual. Maka dari itu, siswa yang memiliki tingkat kemampuan visual lebih rendah cenderung lebih sulit memahami konsep matematika siswa pada materi teorema Pythagoras. Terlepas dari hal diatas, meskipun belum tercapai secara maksimal pemahaman konsep matematika siswa pada materi teorema Pythagoras yang mengikuti pembelajaran TANDUR berbantuan mathlet Geogebra lebih baik daripada siswa yang mengikuti pembelajaran TANDUR.

\section{KESIMPULAN}

Berdasarkan hasil analisis data penelitian dan pembahasan yang telah diuraikan pada bab sebelumnya, dapat disimpulkan hal-hal sebagai berikut. 
1. Pembelajaran TANDUR berbantuan mathlet Geogebra berpengaruh positif terhadap pemahaman konsep matematika siswa pada materi teorema Pythagoras. Hal ini ditunjukkan dengan rata-rata skor tes pemahaman konsep matematika yang diperoleh siswa.

2. Pada kelompok siswa yang memiliki tingkat kemampuan visual lebih tinggi, pemahaman konsep matematika siswa pada materi teorema Pythagoras yang mengikuti pembelajaran TANDUR berbantuan mathlet Geogebra lebih baik daripada siswa yang mengikuti pembelajaran TANDUR.

3. Pada kelompok siswa yang memiliki tingkat kemampuan visual lebih rendah, pemahaman konsep matematika siswa pada materi teorema Pythagoras yang mengikuti pembelajaran TANDUR berbantuan mathlet Geogebra lebih baik daripada siswa yang mengikuti pembelajaran TANDUR.

\section{REFERENSI}

Agustina, L. (2016). Upaya Meningkatkan Kemampuan Pemahaman Konsep dan Pemecahan Masalah Matematika Siswa SMP Negeri 4 Sipirok Kelas VII melalui Pendekatan Matematika Realistik (PMR). EKSAKTA: Jurnal Penelitian dan Pembelajaran MIPA, 1(1).

Anggraini, G. R., \& Ariyanto, M. P. (2017). Analisis Kesulitan Pemahaman Konsep pada Materi Pythagoras di Kelas VIII SMP Negeri 3 Kartasura (PhD Thesis). Universitas Muhammadiyah Surakarta.

Astawa, I. W. P. (2004). Meningkatkan Kualitas Proses dan Hasil Pembelajaran Matematika melalui Optimalisasi Representasi Pembelajaran dalam Rangka Pembelajaran Kuantum. Jurnal Pendidikan dan Pengajaran, 37(4), 1-13.

Cai, J., \& Ding, M. (2017). On Mathematical Understanding: Perspectives of Experienced Chinese Mathematics Teachers. Journal of Mathematics Teacher Education, 20(1), 5-29. https://doi.org/10.1007/s10857-015-9325-8

DePorter, B. dkk. 2010. Quantum Teaching "Mempraktikkan Quantum Teaching di Ruang-Ruang Kelas”. Bandung: Kaifa.

Eugen Ljajko. 2013. "Development of Ideas in A GeoGebra - Aided Mathematics Instruction". Mevlana Internasional Journal of Education, Vol.3 (3) (hlm. 1--7).

Fermantika, E. (2012). Penerapan Metode TANDUR pada Pembelajaran Matematika Siswa KELAS VIII SMPN 12 PADANG TAHUN PELAJARAN 2011/2012. Jurnal Pendidikan Matematika, 1(1).

Foster, C. (2013). Problems with Generalising: Pythagoras in N Dimensions. Australian Senior Mathematics Journal, 27(1), 8-11.

Hanifah, E. H. 2011. Identifikasi Kesalahan Siswa dalam Menyelesaikan Soal Cerita Matematika Materi Sistem Persamaan Linier Dua Variabel Berdasarkan Metode Analisis Kesalahan Newman (Studi Kasus SMP Bina Bangsa Surabaya). Skripsi. Tidak diterbitkan. IAIN Sunan Ampel Surabaya.

Linto, R. L. (2012). Kemampuan Koneksi Matematis dan Metode Pembelajaran Quantum Teaching dengan Peta Pikiran. Jurnal Pendidikan Matematika, 1(1).

Mrstik, S. L., \& Pearl, C. (2018). The Effects of Mentor Instruction on Teaching Visual Supports to Novice, Special Education Teachers. International Journal of Instruction, 11(1), 411-424. https://doi.org/10.12973/iji.2018.11128a

Muchyidin, A. (2012). Pengaruh Penguasaan Teorema Pythagoras terhadap Kemampuan Siswa dalam Menyelesaikan Soal-soal Garis Singgung Lingkaran Kelas VIII SMPN 1 Leuwimunding. Eduma: Mathematics Education Learning and Teaching, 1(2).

Mwakapenda, W. (2004). Understanding Student Understanding in Mathematics. Pythagoras, (60), 2835 .

NCTM. (2000). Principles and Standards for School Mathematics. Reston, VA: National Council of Teachers of Mathematics.

Percy, A., \& Carr, A. (2010). Leaning on Socrates to Derive the Pythagorean Theorem. Australian Mathematics Teacher, 66(2), 8-12.

Priyanto, A., \& Trapsilasiwi, D. (2015). Analisis Kesalahan Siswa dalam Menyelesaikan Soal Cerita Matematika Pokok Bahasan Teorema Pythagoras Berdasarkan Kategori Kesalahan Newman di Kelas VIII A SMP Negeri 10 Jember. 
ISSN. 2621-9832

JURNAL MathEdu (Mathematic Education Journal) http://journal.ipts.ac.id/index.php/MathEdu Vol. 4 No. 2 Juli 2021

Rahayu, S. (2016). Analisis Kesalahan Siswa dalam Menyelesaikan Soal-Soal Kesebangunan. JURNAL E-DuMath, 2(1).

Sulistyawan, M. A., \& Ariyanto, M. P. (2017). Analisis Kesalahan Siswa Kelas VIII dalam Menyelesaikan Soal Cerita pada Materi Teorema Pythagoras di SMP Muhammadiyah 5 Surakarta Tahun Ajaran 2016/2017 (PhD Thesis). Universitas Muhammadiyah Surakarta.

Sultan, A. (2009). An Ordinary but Surprisingly Powerful Theorem. Australian Senior Mathematics Journal, 23(2), 47-58.

Supardi. (2011). Penelitian Tindakan Kelas (Classroom Action Research) Beserta Sistematika Proposal dan Laporannya. Jakarta : Bumi Aksara

Suweken, Gede. 20013. Pelatihan Program Aplikasi GeoGebra sebagai Upaya untuk Meningkatkan Keprofesionalan Guru SMP di Kecamatan Buleleng. Undiksha: Laporan Pengabdian Kepada Masyarakat

Trisnawati, T., \& Wutsqa, D. U. (2015). Perbandingan Keefektifan Quantum Teaching dan TGT pada Pembelajaran Matematika Ditinjau dari Prestasi dan Motivasi. Jurnal Riset Pendidikan Matematika, 2(2), 296-307.

Wibawa, H., \& Masduki, S. S. (2017). Analisis Pemahaman Konsep Matematika Siswa dalam Menyelesaikan Soal Materi Himpunan Berdasarkan Taksonomi Solo (Structure Of Observed Learning Outcomes) Pada Siswa Kelas VII SMP Negeri 2 Baki (PhD Thesis). Universitas Muhammadiyah Surakarta.

Yigit Koyunkaya, M. (2016). Mathematics Education Graduate Students' Understanding of Trigonometric Ratios. International Journal of Mathematical Education in Science and Technology, 47(7), 1028-1047. https://doi.org/10.1080/0020739X.2016.1155774 